\title{
The dissemination of English philosophical works in Spain via translations: The case of Siro García del Mazo's Fundamentos de la moral (1881) from The Data of Ethics (1879) by Herbert Spencer
}

\author{
La divulgación de obras de filosofía inglesas en España a través de \\ sus traducciones: El caso de Fundamentos de la moral (1881) de Siro García \\ del Mazo a partir de The Data of Ethics (1879) de Herbert Spencer
}

\author{
Juan Ramírez-Arlandi
}

Universidad de Málaga. jramirez@uma.es

Recibido: 30/04/2017. Aceptado: 14/11/2017

Resumen: La difusión de la literatura filosófica en inglés en España durante el último cuarto del siglo XIX conlleva necesariamente el estudio detallado de algunas de las obras de Herbert Spencer. Sus posicionamientos más radicales no pasaron desapercibidos para una élite de intelectuales españoles que pronto tradujeron sus obras para así introducir tales ideas en el contexto español. A tenor de ello, este trabajo se centra en la traducción Fundamentos de la moral (1881) vertida por Siro García del Mazo a partir de The Data of Ethics (1879) de Spencer para, desde un punto de vista descriptivo, ofrecer una rigurosa revisión crítica y un análisis de la traducción de una obra filosófica representativa a finales del siglo XIX.

Palabras clave: traducción de textos filosóficos; normas; paratextos; mediación; García del Mazo.

\begin{abstract}
The dissemination of English philosophical literature in Spain during the last quarter of the nineteenth century calls for an in-depth study of some of the works of Herbert Spencer. His most radical views were recognised by an elite group of Spanish intellectuals who translated his works shortly after the original publication in order to introduce these ideas into the Spanish context. Accordingly, this paper examines the translation of Fundamentos de la moral (1881) rendered by Siro García del Mazo from Spencer's The Data of Ethics (1879) so as to provide -from a descriptive point of viewa thorough critical revision and analysis of a representative philosophical work from the late nineteenth century.
\end{abstract}

Keywords: translation of philosophical texts; norms; paratexts; mediation; García del Mazo.

》 Ramírez-Arlandi, Juan. 2017. "The dissemination of English philosophical works in Spain via translations: The case of Siro García del Mazo's Fundamentos de la moral (1881) from The Data of Ethics (1879) by Herbert Spencer". Quaderns de Filologia: Estudis Literaris 22: 255-276. doi: 10.7203/qfed.22.11262 



\section{Introduction}

The second half of nineteenth-century England witnessed the propagation of political, social, and philosophical movements that enriched the ideological panorama. Herbert Spencer (1820-1903) was one of the leading figures who engaged in vigorous debates about different controversial issues of the time. Within his vast body of work, philosophy ranks as one of his main areas of interest. Taking this into consideration, this article initially explores how one of his philosophical works, The Data of Ethics, was translated into Spanish shortly after its original publication and pays specific attention to the agents (translators, publishers...) that contributed to its dissemination. As far as its methodology is concerned, and bearing in mind that philosophical translation is quoted among the "most normoriented studies" (Toury, 1995: 57), this work essentially reproduces Toury's norm-based division into initial and translational norms and is adapted for the sake of clarity into two main sections. First, the preliminary analysis deals with the translation policy, or the choice of texts to be translated, as well as the directness of the translation. Second, the operational analysis accounts for both matricial and textuallinguistic norms in light of the initial norm or subscription to either the source or target pole.

\subsection{Preliminary analysis}

Within descriptive frameworks of analysis, preliminary norms encompass translation policies and considerations of the directness of translation. The former deals with the choice of source texts as well as the typology of text to be translated, whereas the latter accounts for a tolerance for mediating languages (Toury, 1995: 58). In this sense, and bearing in mind that (i) both source and target texts could not necessarily share similar status or systemic space in their systems; (ii) translations very often fill in gaps in target cultures; and (iii) translations may function themselves as source texts, a proper contextualization of

\footnotetext{
* The present research has been funded by the Ministry of Economy and Competitiveness of the Government of Spain (Research Project La Traducción de Clásicos en su Marco Editorial: Una Visión Transatlántica FFI2013-41743-P, National Scientific Research, Development and Technological Innovation Plan). This grant is hereby gratefully acknowledged.
} 
the set of texts under scrutiny certainly becomes indispensable (Toury, 1995: 267; 29).

\subsubsection{The source text in context}

The Data of Ethics (henceforth The Data) by Herbert Spencer was first published as an independent work in 1879 by his publisher, par excellence, Williams and Norgate (Letter no. 3519). Thanks to its founders, Frederic Norgate (1808-1908) and Edmund Sydney Williams (1817-1891), this publisher gained an enviable reputation among academic and scientific circles during the second half of the nineteenth century for the quality and scope of its series. Soon after it was founded in 1843, it became a benchmark of quality specializing in scientific works in Great Britain.

The Data is part of a major work entitled The Principles of Ethics, which was published in several different phases. The first volume included three different parts: Part I The Data of Ethics (1879); Part II The Inductions of Ethics (1892); and, Part III The Ethics of Individual Life (1892). The second volume comprised another three parts: Part IV The Ethics of Social Life: Justice (1891); Part V The Ethics of Social Life: Negative Beneficence (1897); and, Part VI The Ethics of Social Life: Positive Beneficence (1897). Spencer himself explains the eccentric order of publication as a consequence of his persistent bad health (The Data, iii), and adds that, in order to make sense of such an irregular arrangement, the respective prefaces should be read in the following order: "Preface to Part I; then that to Part IV; Preface to Vol. I; and then that to Vol. II". Likewise, Spencer explains that these prefaces might be used not only as a reading guide but also to account for some repetitions that can be observed after the separate publication of each preface. In The Data Spencer openly admits that the study of ethics is, in itself, one of the pillars of his vast and impressive philosophical system, in which he sets out to dissect the intrinsic nature of human conduct, the different forms to judge it, the conflict between egoism and altruism, and, finally, what he refers to as absolute ethics.

\subsubsection{The translated text(s) in context}

Following the original English publication in 1879, the first Spanish translation, Fundamentos de la moral, was published in 1881 in the 
series "Biblioteca Científico-Literaria" printed by the "Administración de la Biblioteca Cientifico-Literaria" in Seville and by the "Librería de Victoriano Suárez" in Madrid (henceforth Fundamentos). This same edition was later reprinted in the same series one decade later (henceforth Fundamentos 1891). According to Jiménez García (1985: 107), the "Biblioteca Científico-Literaria" had been founded by two distinguished followers of Krause's philosophy: Manuel Sales y Ferré and Francisco José Barnés Salinas, professors of Historical Geography and Universal History, respectively, at the University of Seville. Some time later, at the same university a group of intellectuals and professors who had defected to Positivism gathered around the very same "Biblioteca Científico-Literaria" (Brotherston, 1964: 224). As to the "Librería de Victoriano Suárez", Escolar Sobrino (1998: 243) points out that its owner was not only a bookseller but up until the first half of the $20^{\text {th }}$ century also edited university textbooks by intellectuals such as Emilio Cotarelo, Ramón Menéndez Pidal and Joaquín Costa, as well as literary works by Pedro Antonio de Alarcón, Concepción Arenal, Ángel Ganivet and Juan Valera in its series "Obras completas".

The title page of this edition reads that Fundamentos had been "vertido directamente del inglés por Siro García del Mazo"”. Born in Madrid in 1850, García del Mazo was forced by family circumstances to move to Soria at a young age. He finished his secondary education in Soria in 1865 (Velarde 2010). He then returned to Madrid to pursue a Law degree at the Universidad Central; however, he failed to graduate in 1871, after a six-year period. Within the professional and literary circles of the Spanish milieu of his time, we find numerous references that verify his extensive and prolific career as a translator from several languages ${ }^{2}$ : English, French, German and Italian.

In parallel, García del Mazo also pursued a wide range of professional and intellectual endeavours in connection with various cultural entities and associations (Ramírez Arlandi, 2012: 275-9). We know that as part of his professional duties he worked as "Jefe de Trabajos Es-

\footnotetext{
${ }^{1}$ García del Mazo also translated other works by Spencer. In 1879 Educación intelectual, moral y física from Education: Intellectual, Moral, and Physical (1861) (Ramírez Arlandi, 2012); in 1885 El individuo contra el Estado from The Man versus the State (1884); in 1886 Estudios politicos y sociales; and in 1903 Hechos y explicaciones from Facts and Comments (1902).

${ }^{2}$ See Appendix.
} 
tadísticos" in the province of Seville; as editor for the journal Revista de Tribunales; and as a journalist for the newspaper La Discusión edited in Madrid (Ossorio and Bernard, 2004: 160). In 1881 García del Mazo is cited to be a founding member of the "Sociedad El Folk-Lore Andaluz", which brought together prominent Seville-based intellectual figures such as Antonio Machado y Núñez, Antonio Machado y Álvarez, Manuel Sales y Ferré, and Joaquín Guichot y Parody, among others (Rodríguez Baltanás, 2002). Brotherston (1964: 224) reports that García del Mazo had forged a close and solid relationship with Antonio Machado y Álvarez, and when the latter died, Luis Montoto, another key figure in this distinguished group of intellectuals, mentioned García del Mazo as one of the closest friends of Antonio's (Pablo Romero, 1982: 35; 39). Likewise, García del Mazo maintained a fruitful relationship with the "Ateneo de Sevilla", an entity that played a leading role in invigorating the cultural life of the Andalusian city. García del Mazo eventually managed to graduate in Law in 1893, an additional achievement bearing in mind that following his earlier enrolment as a Law student in 1865 he had divided his time between his professional duties as a public servant, cultural scholar and translator (Velarde 2010). By the end of the nineteenth century he had been awarded several promotions and in his role as head of the Statistical Authority was required to settle in Madrid. Nonetheless, due to poor health he moved back to Seville and eventually died in 1911 (Velarde, 2010).

\subsubsection{Directness of translation}

Although the title page of Fundamentos reads that it had been "vertido directamente del inglés por Siro García del Mazo", at this point, when studying the translation of English literary and non-literary texts of the time, we must rigorously refer to the mediating role played by French versions. This fact becomes even more evident if we consider Spencer's works and other versions rendered by García del Mazo (Ramírez Arlandi, 2007: 2939; 2012: 32560). Immediately after its original publication, The Data was translated into French in 1880 in Paris with the title Les bases de la morale évolutionniste by "Ancienne Libraire Germer Baillière" in its series "Bibliothèque scientifique internationale". Although it has not been possible to directly access the first edition, for our research we have used the fifth edition published in 1892 (hence- 
forth Les Bases). Notwithstanding this difficulty, we can affirm that Fundamentos is presumably an indirect translation from The Data via the French Les Bases, as we will prove in the present paper.

\section{Operational analysis}

Operational norms, which include both matricial and textuallinguistic, play a pivotal role within descriptive studies. As far as this section is concerned, the former subtype governs "the degree of fullness of translation", its "actual distribution", and the "textual segmentation"; whereas the latter determines the "selection of material" or choices made to express or set forth the translated text (Toury, 1995: 589).

\subsection{Matricial analysis}

In regard to the fullness of translation, the consideration of additions becomes essential. Fundamentos reproduces an extraneous footnote which is not found in The Data, but which is present in Les Bases. This leads us to affirm that García del Mazo probably used the earlier 1880 French edition when he set out to translate his own version one year later.

\begin{tabular}{|c|c|c|}
\hline The & & Fun \\
\hline $\begin{array}{l}\text { ceding volumes } \\
\text { with morals as } \\
\text { nceived. (...), let } \\
\text { observe what data } \\
\text { iished by these. } \\
\text { l take in succes- } \\
\text { e physical view } \\
\text { logical view the } \\
\text { logical view and } \\
\text { iological view. }\end{array}$ & $\begin{array}{l}\text { Les ouvrages précé- } \\
\text { dents }{ }^{1} \text { ont préparé la } \\
\text { voie pour l'étude de la } \\
\text { morale ainsi comprise. } \\
\text { 1. Premiers principes, } \\
\text { Principes de biologie, } \\
\text { (...) la Bibliothèque } \\
\text { scientifique interna- } \\
\text { tionale, cinquième } \\
\text { édition. }\end{array}$ & $\begin{array}{l}\text { Las obras precedentes } \\
\text { (1) han preparado el } \\
\text { camino al estudio de } \\
\text { la moral así compren- } \\
\text { dida. } \\
\text { (1) Primeros princi- } \\
\text { pios, Principios de } \\
\text { Biología (...) en la } \\
\text { Biblioteca científicoin- } \\
\text { ternacional, quinta } \\
\text { edición. }\end{array}$ \\
\hline
\end{tabular}

Table 1. Additions (footnote) 
In addition, it is necessary to mention that García del Mazo intervenes in Fundamentos with the addition of a three-paragraph "NOTA" at the end of Chapter XII, which is not included in either The Data or in Les Bases. In this "NOTA" García del Mazo reflects upon the negative consequences of parents' egotistical behaviour-patterns on young people (Fundamentos, 2378):

(...) en la resurreccion del tipo de organizacion social producido por las actividades agresivas, con el decaimiento del nivel moral que le acompaña.

NOTA. Aprovecho esta circunstancia para manifestar una consideracion que se me ha ocurrido despues de tirada la edicion primera de la presente obra.

Admitido el principio de la herencia moral y fisica, se sigue que, habitualmente, padres egoistas engendraran hijos tambien egoistas. (...) El poema de Browming, "Halbert y Hob" pone de manifiesto esta verdad. La mayor parte de la felicidad personal (...) así se mejora la conducta hasta convertir el hogar doméstico en asilo de paz y bienandanza.

Regarding the actual distribution of materials, we can state that paratexts in Fundamentos reproduce the same twelve footnotes which Spencer had originally included in The Data. Out of them, nine are bibliographic references (Table 2) alluding to other authors' books and contributions which Spencer considered relevant for his own expository and argumentative purposes.

\begin{tabular}{|l|l|}
\hline The Data $(163)$ & Fundamentos $(179)$ \\
\hline * Constitutional Code, chap. xvi, & (1) Código constitucional, capítulo \\
Supreme Legislative-Section vi, & XVI, Legislación suprema, sección \\
Omni-competence. & VI, Omnipotencia. \\
\hline
\end{tabular}

Table 2. Bibliographic reference

García del Mazo deviated from this norm only once when he transferred the content of a footnote into the main text of the work (Table 3) without providing reasons to justify such a change on the grounds of, for example, the importance of this source to the overall content of both The Data and Fundamentos, or the reader's correct understanding of the Spanish version: 


\begin{tabular}{|l|l|}
\hline The Data (248) & Fundamentos (269) \\
\hline $\begin{array}{l}\text { As elsewhere pointed out, cadences } \\
\text { are the comments of the emotions on } \\
\text { the propositions of the intellect.* }\end{array}$ & $\begin{array}{l}\text { Como hicimos observar en otra par- } \\
\text { te, (Ensayo acerca del origen y fun- } \\
\text { ciones de la música) las cadencias } \\
\text { son los comentarios del sentimiento } \\
\text { acerca de las proposiciones de la } \\
\text { * See Essay on "The Origin and }\end{array}$ \\
Function of Music." & incia. \\
\hline
\end{tabular}

Table 3. Bibliographic footnote inserted into the main text

The close analysis of paratexts reveals the existence of a process of revision aimed at publishing more accurate texts. This is demonstrated, for example, by the partially correct referencing of bibliographic footnotes, which contained some misprints in the earlier 1881 version even though some other typographical mistakes (Table 4) were still reprinted ten years later.

\begin{tabular}{|c|c|c|}
\hline The Data (176) & Fundamentos (193-4) & Fundamentos (1891: 248) \\
\hline $\begin{array}{l}\text { This is well shown by } \\
\text { the great insensibility } \\
\text { of idiots-blows, cuts, } \\
\text { and extremes of heat } \\
\text { and cold, being borne } \\
\text { by them with indiffer- } \\
\text { ence.* }\end{array}$ & $\begin{array}{l}\text { Vése esto claramente } \\
\text { en la gran insensibili- } \\
\text { dad de los idiotas que } \\
\text { soportan con indife- } \\
\text { rencia los golpes, he- } \\
\text { ridas y los rigores de } \\
\text { las temperaturas mas } \\
\text { extremadas (1). }\end{array}$ & $\begin{array}{l}\text { amente en la } \\
\text { lidad de los } \\
\text { portan con } \\
\text { s golpes, } \\
\text { os rigores } \\
\text { turas más } \\
\text { ). }\end{array}$ \\
\hline $\begin{array}{l}\text { * On Idiocy and Im- } \\
\text { becility, by William } \\
\text { W. Ireland, M. D., p. } \\
2556 .\end{array}$ & $\begin{array}{l}\text { no y de } \\
\text { por } \\
\text { D. }\end{array}$ & $\begin{array}{l}\text { (1) Del idiotismo y de la } \\
\text { imbecilidad, por William } \\
\text { W. M. D. páginas } 2556 .\end{array}$ \\
\hline
\end{tabular}

Table 4. Typographical mistakes

The other three footnotes reproduce comments made by Spencer aimed at either illustrating some points and ideas (Table 5) or explaining decisions he made in regard to the overall structural organization of The Data (Table 6). 


\begin{tabular}{|l|l|}
\hline The Data (94) & Fundamentos (106) \\
\hline $\begin{array}{l}\text { (...) by over-study continued regard- } \\
\text { less of discomfort and the cravings } \\
\text { for fresh air and exercise.* }\end{array}$ & $\begin{array}{l}\text { (..) por el exceso del trabajo, no } \\
\text { obstante el malestar sentido y la ne- } \\
\text { cesidad experimentada de aire puro } \\
\text { y ejercicio. (1) }\end{array}$ \\
$\begin{array}{l}\text { * I can count up more than a dozen } \\
\text { such cases among those personally } \\
\text { well known to me. }\end{array}$ & $\begin{array}{l}\text { (1) Puedo contar más de una docena } \\
\text { de casos entre aquellos que conozco } \\
\text { personalmente.(N. del A.) }\end{array}$ \\
\hline
\end{tabular}

Table 5. Illustrative footnote

\begin{tabular}{|l|l|}
\hline The Data (259-60) & Fundamentos (283) \\
\hline $\begin{array}{l}\text { (...) but by all men who perform any } \\
\text { processes of moral reasoning."* }\end{array}$ & $\begin{array}{l}\text { (..) si que tambien por cuantos } \\
\text { hombres son capaces de razonar en } \\
\text { moral» (1.) }\end{array}$ \\
$\begin{array}{l}\text { * I do not find this passage in the } \\
\text { second edition; but the omission of } \\
\text { it appears to have arisen not from } \\
\text { any change of view but because it } \\
\text { did not naturally come into the re- } \\
\text { cast form of the argument which the } \\
\text { section contains. }\end{array}$ & $\begin{array}{l}\text { (1.) Se han omitido estas líneas en } \\
\text { la segunda edicion; pero esto parece } \\
\text { obedecer mas bien que á un cambio } \\
\text { en armonía el texto con la forma } \\
\text { nueva dada al argumento (N. del A.) }\end{array}$ \\
\hline
\end{tabular}

Table 6. Explanatory footnote

In light of this, segmentation may become a fully descriptive tool illustrating the complex relationships seen between the The Data, Fundamentos, and Les Bases. For example, both The Data and Fundamentos exhibit the same internal sectional divisions: a preface, a list of contents, and sixteen chapters. The titles for each of these chapters literally reproduce those from The Data, thus indicating a clear adherence and subscription "to the norms of the source text, and through them to the norms of the source language and culture" (Toury, 1995: 56). However, this adequacy to the source text is not observed when analysing paragraph segmentation. Before evaluating whether we can make a set of norms mirroring some of the traditions or models of segmentation explicit, it is necessary to point out two variants: (i) fragments in which 
several paragraphs from The Data have been merged into a single unit in Fundamentos; and, conversely, (ii) García del Mazo's decision to create new paragraphs from a single, original one in The Data. Regarding (i), we find seven passages in which the paragraph segmentation of the source text has been modified, and, as a result, several units from The Data have merged into one single paragraph by García del Mazo (Table 7). Six (6) of these instances are exclusively found in the Spanish version whereas only one (1) reproduces the same pattern of the French text, which reveals that García del Mazo made subjective and free use of the French version.

\begin{tabular}{|c|c|c|}
\hline The Data (44) & Les Bases (37) & Fundan \\
\hline $\begin{array}{l}\text { (...) and the ideal goal } \\
\text { to the natural evolu- } \\
\text { tion of conduct there } \\
\text { recognized, we here } \\
\text { recognize as the ideal } \\
\text { standard of conduct } \\
\text { ethically considered. } \\
\text { The acts ad- } \\
\text { justed to ends, (...) }\end{array}$ & $\begin{array}{l}\text { Le but idéal que nous } \\
\text { avons d'abord dû as- } \\
\text { signer á l'évolution } \\
\text { naturelle de la conduite } \\
\text { nous donne mainten- } \\
\text { ant la règle idéale de la } \\
\text { conduite considérée au } \\
\text { point de vue moral. } \\
\text { Les actes adaptés à } \\
\text { des fins, }(\ldots)\end{array}$ & $\begin{array}{l}\text { El fin ideal que hemos } \\
\text { debido asignar prime- } \\
\text { ramente á la evolución } \\
\text { natural de la conducta } \\
\text { nos da ahora la regla } \\
\text { ideal de ésta considera- } \\
\text { da bajo el punto de vista } \\
\text { moral. Antes, mostra- } \\
\text { mos cómo la adaptacion } \\
\text { de actos }(. . .)\end{array}$ \\
\hline
\end{tabular}

Table 7. Paragraph reduction

As to (ii), there are seventy-six examples in Fundamentos where García del Mazo intervenes to establish new paragraphs. These, in turn, can be further classified into four subtypes, depending on the number of resulting new units or singled-out paragraphs: two, three, four, or five (Table 8). Thus, we observe fifty; nineteen; three; and four instances in which an original paragraph is divided into two; three; four; and five units, respectively. 


\begin{tabular}{|l|c|c|c|c|}
\hline Chapter & $1<2$ units & $1<3$ units & $1<4$ units & $1<5$ units \\
\hline Preface & - & - & - & - \\
\hline I.- & 2 & - & - & - \\
\hline II.- & 3 & 1 & - & - \\
\hline III.- & 5 & 1 & - & - \\
\hline IV.- & 3 & 1 & 2 & - \\
\hline V.- & 6 & 1 & - & - \\
\hline VI.- & 10 & 4 & - & - \\
\hline VII.- & 5 & 3 & - & 2 \\
\hline VIII.- & 1 & 1 & - & - \\
\hline IX.- & 5 & - & - & 1 \\
\hline X.- & 2 & 1 & 1 & - \\
\hline XI.- & - & 1 & - & - \\
\hline XII.- & 1 & - & - & - \\
\hline XIII.- & 1 & 1 & - & - \\
\hline XIV.- & 1 & 2 & - & - \\
\hline XV.- & 5 & 2 & - & 1 \\
\hline XVI.- & - & - & - & - \\
\hline Total & $\mathbf{5 0}$ & $\mathbf{1 9}$ & $\mathbf{3}$ & $\mathbf{4}$ \\
\hline
\end{tabular}

Table 8. New singled out paragraphs

For illustrative purposes only, the analysis of the four instances in which an original paragraph from The Data $(1157 ; 1245 ; 15960)$ was divided into five different ones proves that García del Mazo reproduced identical segmentation from Les Bases $(99101 ; 1079 ; 1378)$ thrice in Fundamentos $(12831 ; 13840 ; 1756)$, whereas he only introduced minor variations once (Table 9). This procedure reveals that García del Mazo did have the French edition at hand, but made subjective and unsystematic use of it when rendering the Spanish version. 


\begin{tabular}{|c|c|c|}
\hline The Data (266) & Les Bases (228) & Fundamentos (289) \\
\hline $\begin{array}{l}\text { (...) Two examples will } \\
\text { suffice. Here is a mer- } \\
\text { chant who loses by the } \\
\text { failure of a man indebt- } \\
\text { ed to him (...) Even if } \\
\text { by borrowing (...) Shall } \\
\text { he ask a friend for a } \\
\text { loan? On the one hand, } \\
\text { (...) Take, again, the } \\
\text { difficulties... }\end{array}$ & $\begin{array}{l}\text { (...) Deux exemples } \\
\text { suffiront. } \\
\text { Voici un marchand } \\
\text { qui perd par la faillite } \\
\text { d'un débiteur (...) En } \\
\text { supposant même qu'en } \\
\text { empruntant (...) De- } \\
\text { mandera-t-il a un de ses } \\
\text { amis de lui prêter ? (...) } \\
\text { Prenez encore les } \\
\text { difficultés qui naissent } \\
\text { souvent (...) } \\
\text { Prenez encore les } \\
\text { difficultés (...) }\end{array}$ & $\begin{array}{l}\text { Bastarán a probarlo dos } \\
\text { ejemplos. } \\
\text { Hé aquí á un comer- } \\
\text { ciante comprometido en } \\
\text { la quiebra de un deudor } \\
(\ldots) \\
\text { Supongamos aun } \\
\text { que pidiendo prestado } \\
(\ldots) \\
\text { Pedirá dinero a cual- } \\
\text { quiera de sus amigos? } \\
(\ldots) \\
\text { Considérense ahora } \\
\text { las dificultades }(. . .)\end{array}$ \\
\hline
\end{tabular}

Table 9. Different paragraph segmentation

\subsection{Textuallinguistic analysis}

Before proceeding with the analysis of the textual-linguistic norms, we should consider some preliminary theoretical and methodological issues. First, the uniqueness and specificity of philosophical literature is not an obstacle for the explanation of certain observable regularities in the description of translation practices since, as Toury (1995: 57) affirms, philosophical translation is a typically normgoverned type of translation. Second, even though initial norms may -or may not- predetermine subsequent considerations at lower and more specific levels of analysis, the notion of norm is "designed to serve first and foremost as an explanatory tool" (Toury, 1995: 57), and this has proven very convenient for our descriptive purposes. Third, as the analysis of textuallinguistic norms demands the previous selection of those sections which, in turn, "should be relevant to the operation which would then be performed on them" (Toury, 1995: 88), we have focused upon a set of items on the grounds of the qualitative nature of this case study. The analysis of these units (philosophical arguments, everyday situations illustrating them and cultural references) will cover the lexical-semantic, pragmatic and referential content of the selected items from The Data as well as their "equivalences" in Fundamentos, with a twofold 
purpose: to check whether the observed regularities conform to the initial norms; and, to indicate the translation technique used (Molina \& Hurtado Albir, 2002).

Initial norms account for the basic choice that translators can make between the requirements of two sources: the pole of adequacy and the pole of acceptability. As Toury explains (1995: 567), adherence to the norms and regularities of the source text determines the adequacy of the translation, whereas "subscription to the norms active in the target culture determines its acceptability" with the inevitable "shifts from the source text". Keeping this distinction in mind, one of the basic features that characterizes the translation of philosophical texts is the predominant adherence to the pole of adequacy. As Pacheco (2014: 4) explains, philosophical translations must emerge as an agreement between both poles, although adequacy must be given some preference (while avoiding the overuse of literal translation). This happens because the translation of philosophical texts is expected to deal with those common communicative systems in which presumably identical ideas might be exchanged (Pacheco, 2014: 4). If the philosophical discourse is built up on relatively long and complex sentences that translators are forced to divide into smaller units at an earlier stage and rearrange later into more elaborate ones (Chico Rico, 2015: 106), it follows that philosophical translated texts must include numerous statements and definitions accounting for the basic tenets of the system exposed, and this argumentative tool, Ladmiral and Brownlie point out, is ultimately responsible for the repeated translation of key concepts by using lemmas with the same morphological stem (Chico Rico, 2015: 104).

Regarding the translation of two key philosophical arguments in Spencer's system, "evolution" and "conduct", we find that García del Mazo generally subscribes to the pole of adequacy. Thus, the original "evolution, tending ever towards selfpreservation, reaches its limit when individual life is the greatest, both in length and breadth" (The Data, 25) is translated almost literally as "la evolucion, en tanto tiende á la conservacion del indivíduo, encuentra su límite, cuando la vida individual alcanza el suyo en duracion y plenitud" (Fundamentos, 35) from the French "l'évolution, tendant toujours à la conservation de l'individu, atteint sa limite lorsque la vie individuelle est la plus grande possible, en longueur et en largeur" (Les Bases, 20). Notwithstanding, the original "the conduct to which we apply the name good, is the relatively 
more evolved conduct; and that bad (...) is relatively less evolved" (The Data, 25), which does not seem to exhibit any linguistic or conceptual difficulties, becomes "la conduite à laquelle convient la qualification de bonne est (...) la plus développée, et que la qualification de mauvaise s'applique à (...) la moins développée" (Les Bases, 20). Inexplicably, García del Mazo translates this same section inaccurately as "la conducta se atrae el calificativo de buena es la más desenvuelta, aplicándose el epíteto de mala á la menos desenvuelta" (Fundamentos, 35). As shown, the translator's limited linguistic competence when translating "evolved" with the meaning of "developed by evolution" (Oxford English Dictionary, henceforth $O E D$ ) for "desenvuelta" prevents the Spanish reader from correctly understanding one of the keystones of Spencer's philosophy.

In the same vein, when discussing both egoism and altruism, the original "sympathy which prompts denial of self to please others, is a sympathy which also receives pleasure from their pleasures" (The Data, 255) does not find an accurate equivalent in "la simpatía que nos impulsa á imponernos un sacrificio para agradar a otra persona, participa del placer que los demás experimentan" (Fundamentos, 277), which to some extent follows the French wording "la sympathie qui porte á se priver soi-même pour plaire à autrui, est une sympathie qui reçoit aussi du plaisir par suite des plaisirs" (Les Bases, 218). "Simpatía", defined as "correspondencia ó afinidad que se observa entre algunos cuerpos por sus propiedades" in the 1869 edition of the Diccionario de la lengua castellana por la Real Academia Española (Nuevo tesoro lexicográfico de la lengua española, henceforth Ntlle), does not address the very semantic content of "sympathy" as the "quality or state of being thus affected by the suffering or sorrow of another; a feeling of compassion or commiseration" (OED).

Spencer's system is inextricably bound to daily life and personal experiences, which accounts for the abundance of references of this kind in The Data. When philosophical arguments are introduced, Spencer often resorts argumentatively to everyday life experiences to support his views of the point under debate. The analysis of these sections reveals that Fundamentos generally conforms to the trend of adequacy in The Data mentioned above (Pacheco, 2014: 4). Refuting the excesses of an exaggerated altruistic fatherhood, Spencer's claim that "[S]imilarly prompted by a high sense of obligation, (...) he daily continues his 
office-work for long hours regardless of hot head and cold feet" (The Data, 195) finds a literal equivalent in "[I]gualmente impulsado por el sentimiento elevado del deber, (...) hay quien prolonga todo los dias largas horas su trabajo, sin inquietarse por que la cabeza le arda y los pies se le hielen" (Fundamentos, 213), except for the transposition (Molina $\&$ Hurtado Albir, 2002: 499) of the noun phrase "todos los dias" instead of the adverb of frequency "daily", following the French version "il persiste tous les jours de longues heures" (Les Bases, 168). In spite of this, the closeness to the French version is altered occasionally when, for instance, Spencer lists the items a debtor offers for compensating his financial obligations: "one of sundry things he possesses-a diamond ornament, a silver vase, a picture, a carriage" (Fundamentos, 152). Interestingly, García del Mazo renders "cualquiera de los objetos que posee; un adorno de diamantes, un vaso de plata, un coche" (Fundamentos, 1678) unexpectedly omitting "picture", thereby departing from the literal French wording "des différents objets qu'il possède, une parure de diamants, un vase d'argent, un tableau, une voiture" (Les Bases, 131).

Cultural references provide interesting material for descriptive studies in as much as the translation of these units demands an extra and conscientious effort by the translator. Within this context, it might happen that the translation of culturally specific concepts is not successfully achieved in the target context for several reasons. One of which deals with the translator's restricted linguistic and cultural competence to provide a solution for a translation problem of this kind. The description of the elaborate combination of motions attributed to human beings produces "manipulations (...) in making weapons (...), or in building canoes and wigwams for permanent uses" (The Data, 65). Two translation techniques, literal translation and borrowing (Molina \& Hurtado Albir, 2002: 499), are used to subscribe to the source pole by reproducing "las manipulaciones laboriosas necesarias á la fabricacion de armas (...) ó por la construccion de canoas y de wigwams de uso permanente" (Fundamentos, 77) from the French "les manipulations laborieuses nécessaires pour la fabrication d'armes (...) ou pour la construction de canots ou de wigwams d'un usage permanent" (Les Bases, 55). Both the French and Spanish texts fail to provide an equivalent to "wigwam" referred to as a "lodge, cabin, tent, or hut of the North American Indian peoples of the region of the Great Lakes and eastward" (OED). The use of this foreignism adds some exoticism to both translated texts since 
"wigwam" is firstly documented in the Spanish lexicon in 1917 when José Alemany y Bolufer entered this lemma into his Diccionario de la Lengua Española with the meaning "Aldea de pieles rojas en América. Choza, tienda de pieles rojas en América" (Ntlle).

When dealing with the relationships between countries and nations, the following reference illustrates how García del Mazo intervenes upon the French version by introducing his own variations. The political and cultural reference to "how in different parts of the world, the unscrupulous greed of conquest cloaked by pretences of spreading the blessings of British rule and British religion" (The Data, 218) shows how the Spanish translator does not deliberately subscribe to the French text. The translator's intervention is demonstrated by the addition of both "las cinco partes del mundo" and "fuente perenne de males" (Fundamentos, 237) from the "dans différentes parties du monde" and "produit de maux" (Les Bases, 187), respectively. In turn, the literal translation "desprovisto de todo escrúpulo é inspirado por la pretension especiosa de difundir" (Fundamentos, 237) unveils García del Mazo's limited linguistic (lexical) competence from the "dépourvu de tout scrupule et inspiré par la prétention spécieuse de répandre" (Les Bases, 187). At the same time, this very literal translation illustrates how García del Mazo adheres to the French version and translates "the blessings of British rule and British religion, is now reacting to the immense detriment of the industrial classes at home" (The Data, 218) using the restricting reference to England instead of the original "at home", corresponding to "Great Britain", as "los beneficios del gobierno y de la religion británica, es fuente perenne de males para las clases industriales de Inglaterra" (Fundamentos, 306) from the French "les bienfaits du gouvernement et de la religion britanniques, produit de maux en retour aux classes industrielles de l'Angleterre" (Les Bases, 187). Finally, Spencer's mention of "[T] he conception set forth (...) would be received with contempt by that Fifeshire regiment of militia, at the time of France-German War" (The Data 257) is a historical reference to a section of the Army established in 1798 . Very occasionally known by the anglicisation "Fifeshire" from the original Fife in Scotland, García del Mazo renders an obscure "La concepción que proponemos será mirada con desprecio por ese regimiento de milicianos del condado de Fifa, (...) en el momento de la guerra francoprusiana" (Fundamentos, 279) for the Spanish reader by translating "condado de Fifa" from the French "du comte de 
Fife" (Les Bases, 220). As with the previously mentioned examples of "sympathy" and "daily" and admitting that "condado de Fifa" could have been rendered without necessarily taking the French version into consideration, we are more inclined to believe that García del Mazo used the mediating text when making his definite choice.

\section{Conclusions}

Within the preliminary analysis, the consideration of both translation policies and directness of translation has enabled us to trace and see in context how the translation of The Data in Spain at the end of the nineteenth century was determined by the intellectual milieu in which García del Mazo pursued his career as a translator as well as by the great tolerance for French as a mediating language.

Both the analysis and subsequent description of the fullness of the translation allow us to infer that on a general basis García del Mazo subscribed to the pole of adequacy by reproducing the wholeness of The Data. He simply deviated from this norm twice when he added two footnotes; one from Les Bases, and another from his own sources, which leads us to affirm that the French mediation did not prevent García del Mazo from subjecting himself to the source pole of acceptability very occasionally. As to the distribution of materials in Fundamentos, the study of footnotes reveals García del Mazo's adherence to the pole of adequacy in general terms. Regarding textual segmentation, we can affirm that Fundamentos reproduces all the sections (Preface, list of Contents, and Chapters) from The Data. Nonetheless, the adequacy to The Data shows significant variations when paragraph segmentation is examined. Interestingly, this detailed study has also shown that such interventions do not generally follow the segmentation pattern from Les Bases, whereby we can conclude that although García del Mazo did have the French edition close at hand, he did not feel constrained by it. Such idiosyncratic behaviour sheds light on and illustrates both the French mediation and the choices made by García del Mazo regarding his own interventions on the translated text as well as his partial adherence to the pole of adequacy. In view of these data, we can affirm that the French mediation became the first step which gave way to other significant interventions on Fundamentos mainly related to the fullness and the segmentation of the contents. 
Admitting that philosophical translation is governed by norms which exhibit an inherently explanatory nature, we have selected three representative items to illustrate our textuallinguistic descriptive analysis. First, the study of the translation of philosophical arguments has shown that García del Mazo generally subscribed to the pole of adequacy from the French version even though occasionally we come across some inaccurate renderings which may eventually endanger the acceptability of Fundamentos to the target Spanish-speaking audience. Second, the analysis of those sections reproducing everyday experiences aimed at exemplifying previous philosophical arguments again attests to the general adherence to the source pole. Nonetheless, this trend should be considered in the context of some translational techniques such as transpositions and omissions, which manifest García del Mazo's deliberate intervention upon the mediating text. Third, the translation of cultural references also provides ample examples of how the initial adherence to the pole of adequacy is called into question in light of García del Mazo's partial linguistic competence in French, which prevents him from providing equivalent lemmas to culturally specific concepts. As mentioned above, García del Mazo intervenes upon the text introducing his own variations through additions and restricting references thus deviating from the pole of adequacy.

\section{Bibliography}

Anoll, Lídia. 2014. "Nuevos cuentos a Ninon" de Émile Zola, en la traducción de Siro García del Mazo (1888). Biblioteca Virtual Miguel de Cervantes. https://goo.gl/ilXSoU [Accessed 03/04/2017].

Brotherston, J. G. 1964. Antonio Machado y Álvarez and Positivism. Bulletin of Hispanic Studies 41(4): 223-9.

Chico Rico, Francisco. 2015. La traducción del texto filosófico: entre la literatura y la ciencia. Castilla. Estudios de Literatura 6: 94112.

Escolar Sobrino, Hipólito. 1998. Historia del libro español. Madrid: Gredos.

García del Mazo, Siro. 1897. Lo que ha hecho el Ateneo. Ateneo y Sociedad de Excursiones de Sevilla. Sevilla: El Orden. 57.

Letter no. 3519. (n.y.). In Darwin Correspondence Project. http://www.darwinproject.ac.uk/DCP-LETT-3519 [Accessed 07/09/2017].

Molina, Lucía \& Hurtado Albir, Amparo. 2002. Translation techniques revisited: a dynamic and functionalist approach. Meta XLVII 4: 498512. 
OED. 2009. Oxford English Dictionary (2 ${ }^{\text {nd }}$ ed.). [CD-ROM]. Oxford: Oxford University Press.

Ossorio y Bernard, Manuel. 2004. Ensayo de un catálogo de periodistas españoles del siglo XIX; reproducción facsímil de la edición de 1904, Madrid, Imprenta y Litografía de J. Palacios, realizada con motivo del centenario del fallecimiento de su autor. Madrid: Ayuntamiento.

Pablo-Romero de la Cámara, María. 1982. Historia del Ateneo de Sevilla. Sevilla: Colegio Oficial de Aparejadores y Arquitectos Técnicos.

Pacheco Costa, Verónica. 2014. La traducción de textos filosóficos ingleses contemporáneos: las notas del traductor. Tonos Digital 26: 1-13.

Ramírez Arlandi, Juan. 2007. Siro García del Mazo, traductor "en vista de" de Spencer: Apuntes sobre la recepción y traducción de textos ensayísticos a finales del siglo XIX. In Zaro Vera, Juan Jesús (ed.) Traductores y traducciones de literatura y ensayo (1835-1919). Granada: Comares, 279-319.

Ramírez Arlandi, Juan. 2011. La mediación francesa en la traducción al castellano de Siro García del Mazo (1879/1884) de Education: Intellectual, Moral, and Physical. In Zaro Vera, Juan Jesús (ed.) La traducción como actividad editorial en la Andalucía del siglo XIX. Sevilla: Alfar, 253-273.

Ramírez Arlandi, Juan. 2012. Recepción y traducción de Herbert Spencer en España. Estudio descriptivo de las traducciones de "Education: Intellectual, Moral, and Physical" (Doctoral dissertation). Málaga: Universidad de Málaga - Departamento de Traducción e Interpretación. [RIUMA]. http://hdl.handle.net/10630/5488

Real Academia Española (RAE). 2001. Nuevo tesoro lexicográfico de la lengua española. Madrid: Espasa. http://ntlle.rae.es/ntlle/SrvltGUILoginNtlle

Toury, Gideon. 1995. Descriptive Translation Studies and beyond. Amsterdam/Philadelphia: John Benjamins.

Velarde, José I. 2010. García del Mazo: de Cantabria a Sevilla y viceversa. Datos biográficos de un traductor en la Sevilla de finales del XIX. Personal communication.

Verdejo, María del Mar. 2008. Apuntes sobre una traducción de Siro García del Mazo: El gobierno representativo de John Stuart Mill. In Zaro, Juan Jesús (ed.) Diez estudios sobre la traducción en la España del siglo XIX. Granada: Atrio, 209-235.

\subsection{Corpus of analysis}

Spencer, Herbert. 1879. The Data of Ethics. London: Williams and Norgate. 
Spencer, Herbert. 1881/1891. Fundamentos de la moral. Sevilla/Madrid: Administración de la Biblioteca Científico-Literaria/Librería de Victoriano Suárez.

Spencer, Herbert. 1892. Les Bases de la Morale Évolutionniste (Cinquième édition). Paris: Ancienne Librairie Germer Baillière.

\section{Appendix}

Translations from English

\begin{tabular}{|c|l|}
\hline Date & Title \\
\hline 1878 & $\begin{array}{l}\text { El gobierno representativo from Considerations on the } \\
\text { Representative Government (1861) by John Stuart Mill (Verdejo, } \\
\text { 2008: 209-235). }\end{array}$ \\
\hline 1888 & $\begin{array}{l}\text { El gobierno popular from Popular Government (1885) by Henry } \\
\text { James Sumner Maine. }\end{array}$ \\
\hline 1890 & $\begin{array}{l}\text { Historia de Asiria: desde el engrandecimiento del Imperio hasta } \\
\text { la caida de Ninive (continuación de Caldea) with a prologue by } \\
\text { Manuel Sales y Ferré from The Story of Assyria from the Rise of the } \\
\text { Empire to the Fall of Nineveh continued from "Chaldea" (1887) by } \\
\text { Zenaïda A. Ragozine. }\end{array}$ \\
\hline 1892 & $\begin{array}{l}\text { Historia de Alemania from Germany. The Story of Nations (1886) } \\
\text { by Sabine BaringGould. }\end{array}$ \\
\hline 1903 & $\begin{array}{l}\text { Sistemas de remuneración industrial from Methods of Industrial } \\
\text { Remuneration (1892) by David Frederick Schloss. }\end{array}$ \\
\hline 1903 & $\begin{array}{l}\text { La civilización occidental from Principles of Western Civilisation } \\
\text { (sic) (1902) by Benjamin Kidd. }\end{array}$ \\
\hline 1907 & $\begin{array}{l}\text { Los veinte ensayos from both Essays: First Series (1841) and } \\
\text { Essays: Second Series (1844) by Ralph Waldo Emerson. }\end{array}$ \\
\hline
\end{tabular}

Translations from French

\begin{tabular}{|c|l|}
\hline Date & Title \\
\hline 1879 & $\begin{array}{l}\text { El cristianismo y la Revolución Francesa from Le christianisme et } \\
\text { la Révolution française (1845) by Edgar Quinet. }\end{array}$ \\
\hline 1888 & $\begin{array}{l}\text { Nuevos cuentos a Ninon from Nouveaux contes à Ninon (1874) by } \\
\text { Émile Zola (Anoll, 2014). }\end{array}$ \\
\hline
\end{tabular}




\begin{tabular}{|l|l|}
\hline Date & Title \\
\hline 1888 & $\begin{array}{l}\text { Aziyadé: (Stamboul, 1876-1877): extracto de notas y cartas de un } \\
\text { oficial de la Marina inglesa from Aziyadé (Stamboul 1876-1877): } \\
\text { extrait des notes et lettres d'un lieutenant de la marine anglaise } \\
\text { entré au service de la Turquie le 10 mai 1876, tué sous les murs de } \\
\text { Kars le 27 octobre 1877 (1879) by Pierre Loti (Julien Viaud). }\end{array}$ \\
\hline 1906 & $\begin{array}{l}\text { El espíritu de las leyes from De l'esprit des loix (1747) by } \\
\text { Montesquieu. }\end{array}$ \\
\hline
\end{tabular}

Translations from German

\begin{tabular}{|l|l|}
\hline Date & Title \\
\hline 1879 & $\begin{array}{l}\text { El darwinismo. Lo verdadero y falso de esta teoría from Wahrheit } \\
\text { und Irrthum im Darwinismus (1875) by Eduard von Hartmann. }\end{array}$ \\
\hline
\end{tabular}

Translations from Italian

\begin{tabular}{|l|l|}
\hline Date & Title \\
\hline 1880 & $\begin{array}{l}\text { El nihilismo: cómo ha nacido, cómo se ha desenvuelto, qué es, qué } \\
\text { quiere from the second edition of Il nichilismo, come è nato, come si } \\
\text { è sviluppato, che cosa e, che cosa vuole (1879) by G. B. Arnaudo. }\end{array}$ \\
\hline
\end{tabular}

